\title{
Sistem Pakar Deteksi Penyakit Pada Tanaman Singkong
}

\section{Expert System to Detect the Disease of Cassava Plants}

\author{
Selviana Yunita ${ }^{1}$, Agung Jasuma ${ }^{2}$, Mat Sudir ${ }^{3}$, Kusrini $^{4}$ \\ 1,2,3,4 Magister Teknik Informatika Universitas Amikom Yogyakarta \\ Jl. Ring Road Utara, Condongcatur, Sleman, Yogyakarta 55281 \\ e-mail: ${ }^{1}$ selviana.yunita.ax@gmail.com, ${ }^{2}$ agung.jasuma@ students.amikom.ac.id, \\ 3 matsudir@gmail.com, ${ }^{4}$ kusrini@ amikom.ac.id
}

\begin{abstract}
Abstrak
Singkong merupakan tanaman pengganti makanan pokok yang banyak ditemukan di Indonesia. Namun penyakit pada singkong menyebabkan berkurangnya produksi singkong. Dibutuhkan seorang pakar untuk dapat mendeteksi dan mencegah penyakit pada singkong agar dapat dilakukan tindakan pencegahan atau perbaikan sejak awal. Namun seorang pakar tidak dapat memberikan diagnosisnya setiap saat kepada petani saat dibutuhkan. Untuk itu dikembangkan suatu aplikasi sistem pakar yang dapat membantu petani mendeteksi penyakit pada tanaman singkong. Aplikasi sistem pakar ini merupakan aplikasi berbasis desktop yang dikembangkan dengan teori Bayes. Teori probabilitas Bayesian digunakan untuk menghitung probabilitas terjadinya suatu peristiwa berdasarkan pengaruh yang didapat dari pengujian. Teori Bayes didasarkan pada prinsip jika terdapat tambahan informasi atau evidence, maka nilai probabilitas dapat diperbaiki, karena itu teori Bayes bermanfaat untuk memperbaiki atau mengubah nilai kemungkinan yang telah ada menjadi lebih baik dengan didukung informasi atau evidence tambahan Skema pengujian dilakukan dengan membandingkan hasil diagnosis sistem dengan hasil diagnosis pakar. Berdasarkan hasil pengujian, keakuratan aplikasi sistem pakar ini adalah $93.33 \%$.
\end{abstract}

Kata kunci-Sistem Pakar, Teori Bayes, Tanaman Singkong

\begin{abstract}
Cassava is a staple food substitute plant that commonly found in Indonesia. But the diseases in cassava cause a reduction in cassava production. An expert is needed to be able to detect and prevent the diseases of cassava plant so the early preventive and remedial actions can be taken. But an expert cannot be available at anytime to the farmer when it needed. For this reason, an expert system application has been developed that can help farmers to detect diseases in cassava plants. This expert system application is a desktop-based application developed with Bayes theory. Bayesian probability theory is used to calculate the probability of occurance of an event based in the effect obtained from the test. The principle of Bayes theory is based on, if there is additional information or evidence, then the probability value can be corrected, therefore Bayes theory is useful to improve or change the value of existing possibilities for the better supported by additional information or evidence. The testing scheme is done by compairing the result of the system diagnosis with the result of expert diagnosis. Based on the test result, the accuracy of the expert system application is $93.33 \%$.
\end{abstract}

Keywords-Expert system, Bayes theory, Cassava plant 


\section{PENDAHULUAN}

Singkong merupakan salah satu tanaman yang banyak ditemukan di Indonesia dan merupakan tanaman dengan banyak manfaat. Salah satu manfaat singkong adalah sebagai bahan pokok pengganti nasi. Berdasarkan data Badan Pusat Statistik pada tahun 2015, diketahui produksi singkong di Indonesia adalah sebesar 21.801.415 ton dalam setahun. Selain sebagai bahan makanan, ubi kayu juga dapat digunakan sebagai bahan baku industri dan pakan ternak. Ubi yang dihasilkan mengandung air sekitar $60 \%$, pati $25-35 \%$, serta protein, serat, mineral, fosfat, dan kalsium. Singkong juga merupakan sumber energi yang lebih tinggi dibanding jagung, ubi jalar, padi, dan sorghum[1]. Provinsi Lampung merupakan penghasil singkong terbesar di Indonesia, namun produksi tersebut pengalami penurunan pada tahun 2016 yang salah satunya disebabkan oleh serangan patogen penyebab penyakit pada singkong[2]. Sehingga penting untuk melakukan identifikasi terhadap hama dan patogen penyebab penyakit dan mengendalikan penyebaran hama dan penyakit tersebut.

Dalam mengidentifikasi suatu penyakit dan hama pada tanaman singkong, dibutuhkan seorang pakar yang mengerti tentang penyakit pada tanaman singkong. Namun faktanya, tidak semua pakar dapat membantu para petani saat dibutuhkan, sehingga petani tidak dapat mengetahui secara cepat dan tepat permasalahan yang terjadi pada tanaman singkong. Berdasarkan permasalah tersebut, penulis merancang suatu sistem pakar yang dapat membantu petani untuk mendeteksi penyakit yang terjadi pada tanaman singkong. Sebuah sistem pakar memungkinkan aplikasi tersebut mendeteksi penyakit dengan pengetahuan layaknya yang dimiliki oleh seorang pakar.

Teori probabilitas Bayesian digunakan untuk menghitung probabilitas terjadinya suatu peristiwa berdasarkan pengaruh yang didapat dari pengujian. Probabilitas Bayes menerangkan hubungan antara probabilitas terjadinya hiptesis $\mathrm{H}_{1}$ dengan terdapat fakta (evidence) $\mathrm{E}$ telah terjadi dan probabilitas terjadinya evidence $E$ dengan syarat hipotesis $\mathrm{H}_{1}$ telah terjadi. Teori Bayes didasarkan pada prinsip jika terdapat tambahan informasi atau evidence, maka nilai probabilitas dapat diperbaiki, karena itu teori Bayes bermanfaat untuk memperbaiki atau mengubah nilai kemungkinan yang telah ada menjadi lebih baik dengan didukung informasi atau evidence tambahan. Adapun rumus untuk teori Bayes adalah[3]:

\section{Diketahui :}

$$
\mathrm{P}\left(\mathrm{H}_{\mathrm{i}} \mid \mathrm{E}\right)=\frac{\mathrm{p}\left(\mathrm{E}_{n}\right.}{\sum_{\mathrm{n}=1}^{\mathrm{n}} \mathrm{p}\left(\mathrm{E}_{\mathrm{n}} \mid \mathrm{H}_{\mathrm{i}}\right) \times \mathrm{p}\left(\mathrm{H}_{\mathrm{i}}\right) \times \mathrm{p}\left(\mathrm{H}_{\mathrm{k}}\right)}
$$

$\begin{array}{ll}\mathrm{P}(\mathrm{Hi} \mid \mathrm{E}) & =\text { merupakan nilai probabilitas munculnya penyakit } \\ & \text { berdasarkan gejala yang diinputkan. } \\ \mathrm{P}(\mathrm{En} \mid \mathrm{Hi}) & =\text { merupakan nilai probabilitas gejala terhadap penyakit. } \\ \mathrm{P}(\mathrm{Hi}) & \text { merupakan probabilitas kemunculan penyakit. } \\ \sum_{\mathrm{k}=1}^{\mathrm{n}} \mathrm{p}(\mathrm{En} \mid \mathrm{Hk}) \times \mathrm{p}(\mathrm{Hk}) & =\text { jumlah nilai porbabilitas dari tiap hipotesa }\end{array}$

Sistem pakar membantu komputer menggunakan penalaran dengan atau mengadopsi keahlian yang dimiliki oleh pakar yang merupakan sistem berbasis komputer yang memiliki dasar pengetahuan seperti seorang pakar untuk menalar dan memecahkan masalah[4]. Penelitian yang dilakukan oleh Awoyelu bertujuan untuk merancang sistem pakar untuk membantu petani memprediksi penyakit pada singkong dengan menggunakan metode fuzzy[5]. Penelitian yang dilakukan oleh Morco, dkk mengembangkan sebuah aplikasi mobile E-rice untuk membantu petani mengidentifikasi masalah pada padi dan menyediakan saran yang dapat dilakukan oleh petani dengan memanfaatkan algoritma aturan dasar[6]. Kemudian penelitian yang dilakukan oleh Agus, dkk bertujuan agar aplikasi sistem pakar dapat membantu petani mendiagnosa 
penyakit yang ada pada cabai merah dengan metode forward chaining dan certainty factor[7]. Selanjutnya yaitu penelitian yang dilakukan oleh Sitanggang, dkk yang bertujuan untuk mengatasi keterbatasan petani dalam mengidentifikasi penyakit pada bawang menggunakan metode forward chaining[8].

\section{METODE PENELITIAN}

Tahapan awal dari penelitian ini adalah melakukan analisis terhadap tujuan dan kebutuhan sistem. Dalam penelitian ini dilakukan beberapa tahap yaitu observasi terhadap data penyakit yang diperoleh melalui Dinas Pertanian Pemerintah Kabupaten Pati, melakukan studi literature dengan mencari referensi penelitian yang sesuai dengan topik penelitian, yaitu perancangan sistem pakar deteksi penyakit pada tanaman singkong. Pada penelitian ini, sistem pakar dibangun dengan menggunakan metode waterfall[9] yang dimulai dengan analisis sistem. Pada tahap ini, dilakukan pengumpulan data terkait gejala-gejala penyakit yang ada pada tanaman singkong, jenis penyakit, informasi, dan keterangan mengenai penyakit singkong.

Tahapan selanjutnya adalah perancangan sistem yang dimulai dengan menetukan fungsionalitas user, perancangan diagram konteks, perancangan basis data, antarmuka pengguna dan kemudian implementasi ke sistem. Tahap terakhir adalah pengujian sistem, dimana pengujian dilakukan dengan mencocokkan hasil diagnosis sistem dengan hasil diagnosis dari pakar.

Gambaran sistem pakar yang akan dirancang terdapat dalam flowchart yang menggambarkan bagaimana sistem gambaran umum sistem. Adapun flowchart sistem pakar deteksi penyakit pada tanaman singkong adalah sebagai berikut:

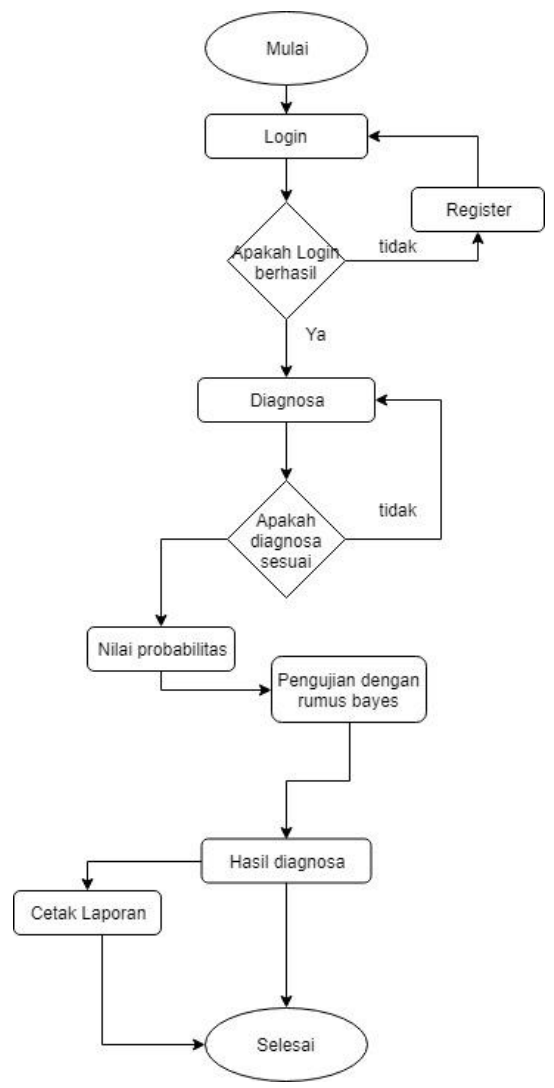

Gambar 1 Flowchart aplikasi sistem pakar 


\section{HASIL DAN PEMBAHASAN}

\subsection{Fungsionalitas User}

Dalam sistem yang akan dibuat terdapat 2 jenis kebutuhan fungsional. Kebutuhan fungsional untuk admin, dan kebutuhan fungsional untuk user. Adapun detail kebutuhan fungsionalnya sebagai berikut :

\section{A. Admin :}

1. Sistem harus dapat merepresentasikan seluruh pengetahuan yang didapat dari pakar kedalam database agar dapat diolah oleh admin.

2. Admin harus dapat mengolah data gejala, penyakit, kemungkinan gejala terhadap penyakit. User dan data aturan pada sistem pakar yang akan dibangun.

3. Admin harus dapat mencetak laporan historis diagnosis yang dilakukan oleh user.

B. User :

1. User harus dapat melakukan diagnosis untuk mengetahui penyakit pada tanaman singkong.

2. User harus dapat menyimpan data riwayat diagnosis.

3. Sistem harus dapat memberikan solusi dan menentukan penyakit terhadap fakta yang diketahui user dengan menerapkan algoritma bayes.

4. User harus dapat melihat informasi gejala dan penyakit.

5. User harus dapat mencetak histori diagnosis yang pernah dia lakukan.

\subsection{Diagram Konteks}

Diagram konteks untuk aplikasi sistem pakar digambarkan pada Gambar 2 dibawah ini:

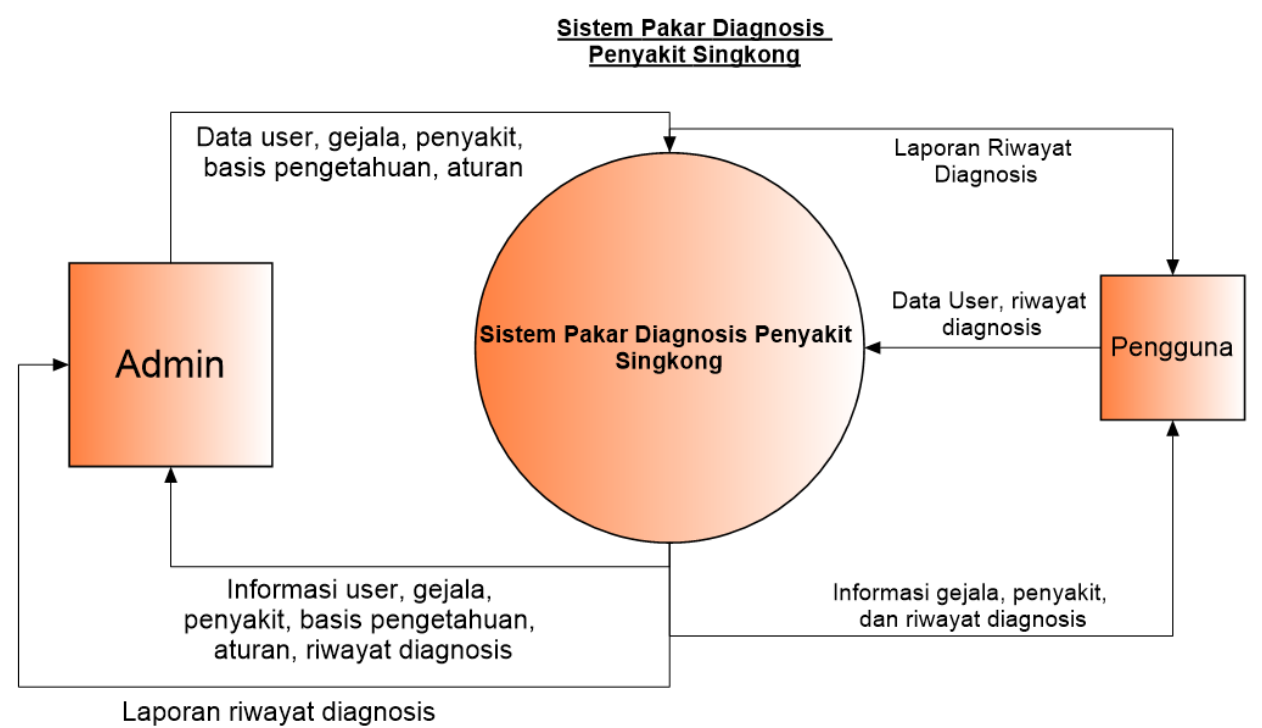

Gambar 2 Diagram Kontek Aplikasi Sistem Pakar

\subsection{Data Flow Diagram}

Dalam aplikasi sistem pakar, terdapat dua user yaitu admin dan pengguna, serta 11 proses utama dengan 6 tabel penyimpanan yang digambarkan dengan menggunakan data flow diagram level 1 pada gambar 3 dibawah ini: 


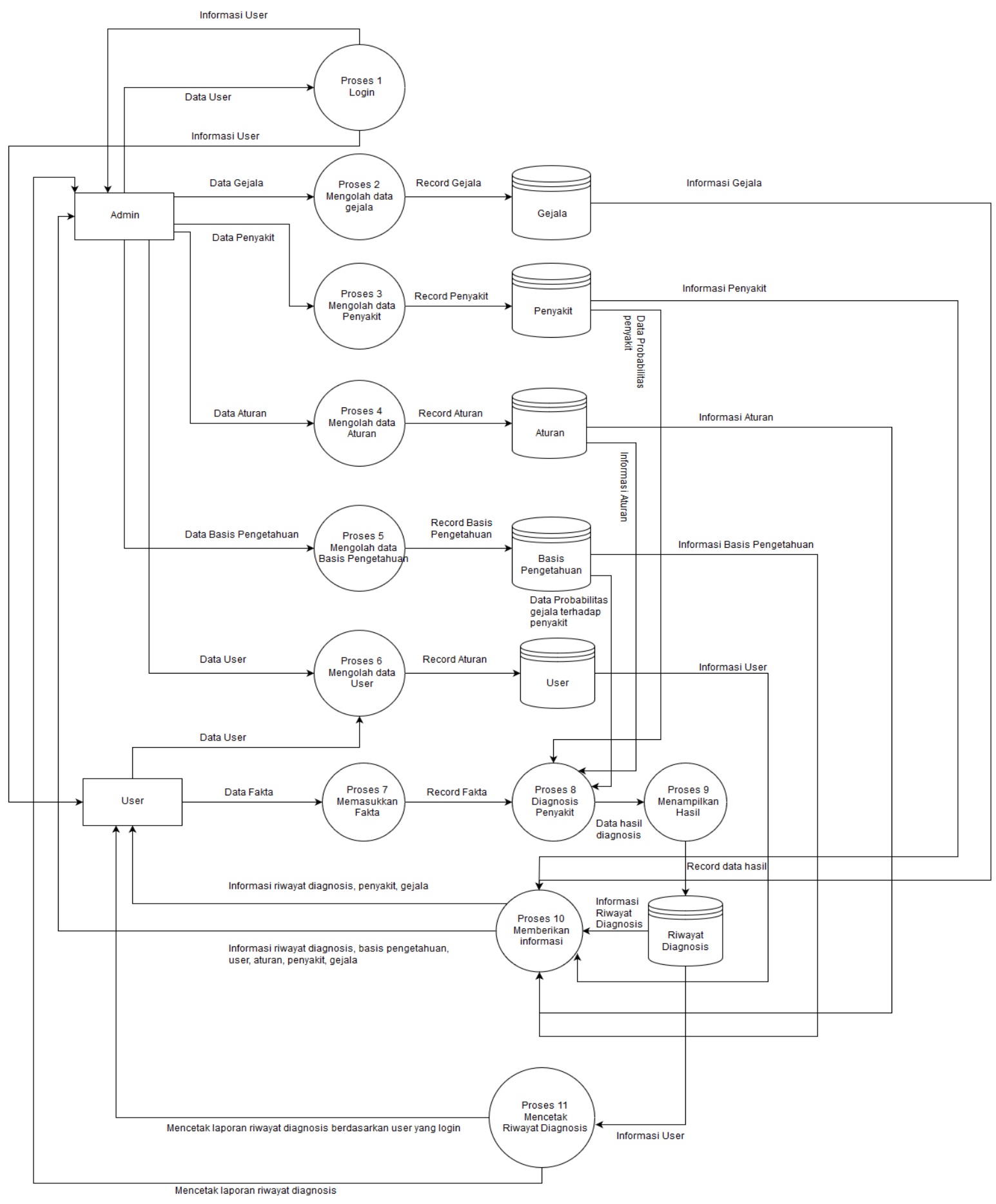

Gambar 3 Data flow Diagram Level 1

\subsection{Relasi Tabel}

Dalam aplikasi sistem pakar, digunakan enam tabel untuk menyimpan data yang dibutuhkan, seperti yang terlihat pada gambar 4 berikut: 


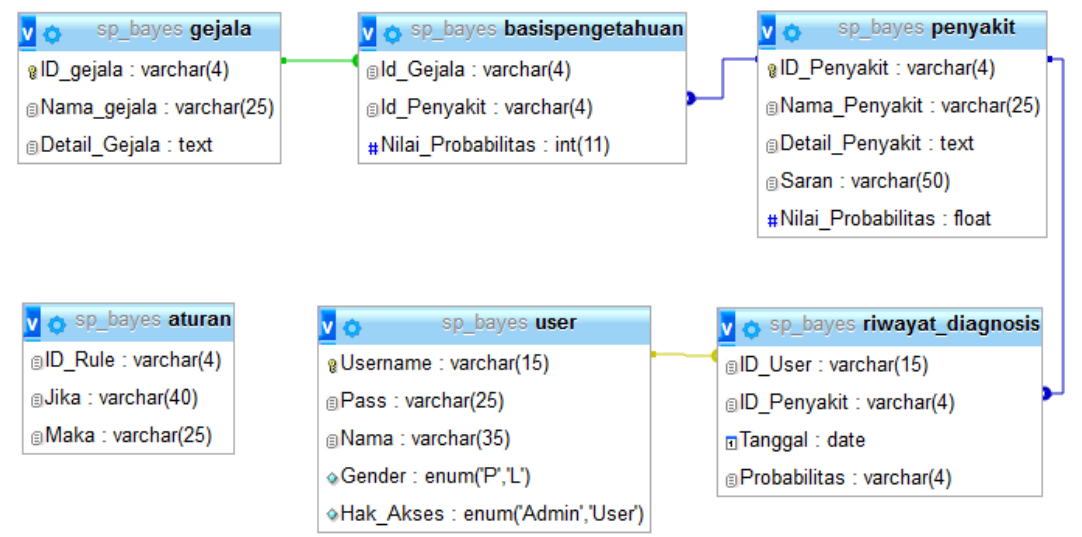

Gambar 4 Relasi Tabel Aplikasi Sistem Pakar

\subsection{Tabel Basis Pengetahuan}

Tabel Basis Pengetahuan berisi kemunculan hipotesa berdasarkan gejala dapat dilihat pada tabel 1 berikut ini:

Tabel 1 Basis Pengetahuan

\begin{tabular}{|c|c|c|c|c|c|c|c|c|}
\hline \multirow[t]{2}{*}{ No } & \multirow[t]{2}{*}{ Gejala } & \multicolumn{7}{|c|}{$\begin{array}{c}\text { Nilai Probabilitas Kemunculan Hipotesa } \\
\text { berdasarkan Gejala atau fakta }\end{array}$} \\
\hline & & H1 & $\mathbf{H 2}$ & H3 & H4 & H5 & H6 & H7 \\
\hline E1 & Penyakit menyerang daun tua & 0.7 & 0.65 & 0.6 & 0.01 & 0.01 & 0.01 & 0.01 \\
\hline E2 & Bercak daun pada bagian bawah & 0.6 & 0.01 & 0.01 & 0.01 & 0.01 & 0.01 & 0.01 \\
\hline E3 & $\begin{array}{l}\text { Bercakputih/coklat pada bagian atas } \\
\text { daun }\end{array}$ & 0.7 & 0.01 & 0.7 & 0.01 & 0.01 & 0.01 & 0.01 \\
\hline E4 & Bercak tepi dibatasi lingkaran ungu & 0.5 & 0.01 & 0.01 & 0.01 & 0.01 & 0.01 & 0.01 \\
\hline E5 & Bercak coklat & 0.75 & 0.6 & 0.01 & 0.01 & 0.01 & 0.01 & 0.01 \\
\hline E6 & Daun berkerut & 0.3 & 0.4 & 0.25 & 0.65 & 0.01 & 0.01 & 0.01 \\
\hline E7 & Daunr ontok / gugur & 0.55 & 0.01 & 0.45 & 0.01 & 0.01 & 0.01 & 0.05 \\
\hline E8 & Daun berlubang & 0.4 & 0.01 & 0.01 & 0.01 & 0.01 & 0.01 & 0.01 \\
\hline E9 & Daun menguning & 0.35 & 0.4 & 0.3 & 0.5 & 0.01 & 0.35 & 0.05 \\
\hline E10 & Daun kering & 0.45 & 0.2 & 0.15 & 0.25 & 0.01 & 0.01 & 0.01 \\
\hline E11 & Ada jamur di bagian bawah daun & 0.2 & 0.25 & 0.01 & 0.01 & 0.01 & 0.01 & 0.01 \\
\hline E12 & Bercak berukuran besar & 0.01 & 0.55 & 0.01 & 0.01 & 0.01 & 0.01 & 0.01 \\
\hline E13 & Bercak sering pada ujung daun & 0.01 & 0.7 & 0.01 & 0.01 & 0.01 & 0.01 & 0.01 \\
\hline E14 & Bercak berbentuk V terbalik & 0.01 & 0.65 & 0.01 & 0.01 & 0.01 & 0.01 & 0.01 \\
\hline E15 & $\begin{array}{l}\text { Daun bagian atas berwarna coklat } \\
\text { merata }\end{array}$ & 0.01 & 0.01 & 0.01 & 0.01 & 0.01 & 0.01 & 0.5 \\
\hline E16 & Daun bagian bawah berwarna abu-abu & 0.01 & 0.3 & 0.01 & 0.01 & 0.01 & 0.01 & 0.5 \\
\hline E17 & $\begin{array}{l}\text { Bagian tengah bercak berwarna abu- } \\
\text { abu penghasil jamur }\end{array}$ & 0.01 & 0.01 & 0.6 & 0.01 & 0.01 & 0.01 & 0.5 \\
\hline E18 & Menyerang daun muda & 0.01 & 0.01 & 0.2 & 0.01 & 0.01 & 0.01 & 0.01 \\
\hline E19 & Menyerang daun dan batang & 0.01 & 0.01 & 0.01 & 0.6 & 0.01 & 0.01 & 0.5 \\
\hline E20 & $\begin{array}{l}\text { Gejala awal berupa lesion berwarna } \\
\text { abu-abu }\end{array}$ & 0.01 & 0.01 & 0.01 & 0.55 & 0.01 & 0.01 & 0.01 \\
\hline E21 & $\begin{array}{l}\text { Lesion dibatasi tulang daun dan } \\
\text { membentuk sudut }\end{array}$ & 0.01 & 0.01 & 0.01 & 0.65 & 0.01 & 0.01 & 0.01 \\
\hline E22 & Lesio meluas menjadi bercak nekrotik & 0.01 & 0.01 & 0.01 & 0.5 & 0.01 & 0.01 & 0.01 \\
\hline E23 & $\begin{array}{l}\text { Perlendiran masa bakteri yang terjadi } \\
\text { pada tangkai, helai daun dan batang }\end{array}$ & 0.01 & 0.01 & 0.01 & 0.3 & 0.01 & 0.01 & 0.7 \\
\hline
\end{tabular}




\begin{tabular}{|c|c|c|c|c|c|c|c|c|}
\hline \multirow[t]{2}{*}{ No } & \multirow[t]{2}{*}{ Gejala } & \multicolumn{7}{|c|}{$\begin{array}{c}\text { Nilai Probabilitas Kemunculan Hipotesa } \\
\text { berdasarkan Gejala atau fakta }\end{array}$} \\
\hline & & H1 & H2 & H3 & H4 & H5 & H6 & H7 \\
\hline E24 & Mati pucuk & 0.01 & 0.01 & 0.01 & 0.45 & 0.55 & 0.01 & 0.7 \\
\hline E25 & $\begin{array}{l}\text { Menyerang permukaan barang, tangkai } \\
\text { daun dan daun }\end{array}$ & 0.01 & 0.01 & 0.01 & 0.01 & 0.8 & 0.01 & 0.7 \\
\hline E26 & $\begin{array}{l}\text { Terdapat tonjolan pada permukaan } \\
\text { batang }\end{array}$ & 0.01 & 0.01 & 0.01 & 0.01 & 0.7 & 0.01 & 0.5 \\
\hline E27 & Tangkai daun mudah patah & 0.01 & 0.01 & 0.01 & 0.01 & 0.6 & 0.01 & 0.01 \\
\hline E28 & Daunlayu & 0.01 & 0.01 & 0.01 & 0.01 & 0.75 & 0.45 & 0.5 \\
\hline E29 & Pengerutan pada bagian gabus & 0.01 & 0.01 & 0.01 & 0.01 & 0.75 & 0.01 & 0.5 \\
\hline E30 & Batang mudah patah & 0.01 & 0.01 & 0.01 & 0.01 & 0.6 & 0.01 & 0.5 \\
\hline E31 & $\begin{array}{l}\text { Menyerang pangkal batang, akar dan } \\
\text { umbi }\end{array}$ & 0.01 & 0.01 & 0.01 & 0.01 & 0.01 & 0.8 & 0.01 \\
\hline E32 & Daun gugur premature & 0.01 & 0.01 & 0.01 & 0.01 & 0.01 & 0.7 & 0.01 \\
\hline E33 & Kerusakan warna pada perakaran & 0.01 & 0.01 & 0.01 & 0.01 & 0.01 & 0.75 & 0.01 \\
\hline E34 & Busuk umbi & 0.01 & 0.01 & 0.01 & 0.01 & 0.01 & 0.6 & 0.01 \\
\hline E35 & $\begin{array}{l}\text { Umbi berwarnagelap dan berbau } \\
\text { busuk }\end{array}$ & 0.01 & 0.01 & 0.01 & 0.01 & 0.01 & 0.7 & 0.7 \\
\hline
\end{tabular}

Dari tabel diatas diketahui terdapat 35 gejala dan 7 penyakit. Dimana masing-masing penyakit dibuat menjadi suatu hipotesa dengan Ketentuan sebagai berikut :

H1 adalah penyakit yang dialami tanaman singkong merupakan penyakit Bercak Daun Coklat. $\mathrm{H} 2$ adalah penyakit yang dialami tanaman singkong merupakan penyakit Bercak Daun Baur. H3 adalah penyakit yang dialami tanaman singkong merupakan penyakit Bercak Daun Putih. $\mathrm{H} 4$ adalah penyakit yang dialami tanaman singkong merupakan penyakit Bakteri Hawar Daun. H5 adalah penyakit yang dialami tanaman singkong merupakan penyakit Antrak nose.

H6 adalah penyakit yang dialami tanaman singkong merupakan penyakit Busuk Pangkal Batang/Akar.

H7 adalah penyakit yang dialami tanaman singkong merupakan penyakit Selaput Lendir Putih.

Perhitungan nilai probalibilitas fakta pada setiap hipotesa yang diperoleh dengan menghitung jumlah gejala yang muncul dibagi dengan jumlah hipotesa pada setiap jenis penyakit yang akan dicari hasilnya. Inferensi jika diketahui fakta yang di dapat dari user adalah sebagai berikut, terdapat bercak putih/coklat pada bagian atas daun (E3) dan Bercak tepi dibatasi lingkaran ungu (E4).

A. Mencocokan fakta user dengan informasi di basis pengetahuan.

1. Nilai probabilitas gejala terhadap hipotesa:
a. $\mathrm{P}(\mathrm{E} 3 \mid \mathrm{H} 1)=0.7$ dan $\mathrm{P}(\mathrm{E} 4 \mid \mathrm{H} 1)=0.5$
b. $\mathrm{P}(\mathrm{E} 3 \mid \mathrm{H} 2)=0.01$ dan $\mathrm{P}(\mathrm{E} 4 \mid \mathrm{H} 2)=0.01$
c. $\mathrm{P}(\mathrm{E} 3 \mid \mathrm{H} 3)=0.7$ dan $\mathrm{P}(\mathrm{E} 4 \mid \mathrm{H} 3)=0.01$
d. $\mathrm{P}(\mathrm{E} 3 \mid \mathrm{H} 4)=0.01$ dan $\mathrm{P}(\mathrm{E} 4 \mid \mathrm{H} 1)=0.01$
e. $\mathrm{P}(\mathrm{E} 3 \mid \mathrm{H} 5)=0.01$ dan $\mathrm{P}(\mathrm{E} 4 \mid \mathrm{H} 2)=0.01$
f. $\mathrm{P}(\mathrm{E} 3 \mid \mathrm{H} 6)=0.01$ dan $\mathrm{P}(\mathrm{E} 4 \mid \mathrm{H} 3)=0.01$
g. $\mathrm{P}(\mathrm{E} 3 \mid \mathrm{H} 7)=0.01$ dan $\mathrm{P}(\mathrm{E} 4 \mid \mathrm{H} 3)=0.01$

2. Nilai probabilitas kemunculan Hipotesa :

$\mathrm{H} 1=0.85, \mathrm{H} 2=0.50, \mathrm{H} 3=0.85, \mathrm{H} 4=0.7, \mathrm{H} 5=0.5, \mathrm{H} 6=0.7, \mathrm{H} 7=0.5$

B. Melakukan perhitungan menggunakan metode Bayes

Penyelesaian :

Mencari : 
Jumlah nilai probabilitas pada setiap hipotesa.

$$
\sum_{\mathrm{k}=1}^{\mathrm{n}} \mathrm{p}\left(\mathrm{E}_{\mathrm{n}} \mid \mathrm{H}_{\mathrm{k}}\right) \times \mathrm{p}\left(\mathrm{H}_{\mathrm{k}}\right.
$$

- $(\mathrm{P}(\mathrm{E} 3 \mid \mathrm{H} 1) \times \mathrm{P}(\mathrm{H} 4 \mid \mathrm{H} 1) \times \mathrm{P}(\mathrm{H} 1))+(\mathrm{P}(\mathrm{E} 3 \mid \mathrm{H} 2) \times \mathrm{P}(\mathrm{H} 4 \mid \mathrm{H} 2) \times \mathrm{P}(\mathrm{H} 2))+(\mathrm{P}(\mathrm{E} 3 \mid \mathrm{H} 3) \times$ $\mathrm{P}(\mathrm{H} 4 \mid \mathrm{H} 3) \times \mathrm{P}(\mathrm{H} 3))$

- $(0.7 \times 0.5 \times 0.85)+(0.01 \times 0.01 \times 0.5)+(0.7 \times 0.01 \times 0.85)+(0.01 \times 0.01 \times 0.7)$ $+(0.01 \times 0.01 \times 0.5)+(0.01 \times 0.01 \times 0.7)+(0.01 \times 0.01 \times 0.5)$

- $0.2975+0.00005+0.00595+0.00007+0.00005+0.00007+0.00005$

- 0.30374

Nilai probabilitas munculnya hipotesa berdasarkan gejala :

$$
\mathrm{P}\left(\mathrm{H}_{\mathrm{i}} \mid \mathrm{E}\right)=\frac{\mathrm{p}\left(\mathrm{E}_{\mathrm{n}}\right.}{\sum_{\mathrm{k}=1}^{\mathrm{n}} \mathrm{p}\left(\mathrm{H}_{\mathrm{i}}\right) \mathrm{x} \mathrm{p}\left(\mathrm{H}_{\mathrm{k}}\right) \mathrm{H}\left(\mathrm{H}_{\mathrm{k}}\right) \mathrm{p}\left(\mathrm{H}_{\mathrm{k}}\right)}
$$

- $\mathrm{P}\left(\mathrm{H}_{1} \mid \mathrm{E}_{3} \mathrm{E}_{4}\right)=\mathrm{p}\left(\mathrm{E}_{3} \mid \underline{\mathrm{H}}_{1}\right) \times \mathrm{p}\left(\mathrm{E}_{4} \mid \underline{\mathrm{H}}_{1}\right) \times \mathrm{p}\left(\mathrm{H}_{1}\right)_{2}=\underline{(0.7 \times 0.5 \times 0.85)}=\underline{0.2975}=\mathbf{0 . 9 7 9 4 5 6 1 1 3 7 8}$

$$
\sum_{k=1}^{n} p\left(E_{n} \mid H_{k}\right) \times p\left(H_{k}\right) \quad 0.30374 \quad 0.30374
$$

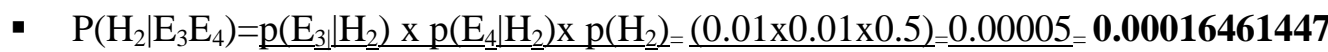

$$
\sum_{\mathrm{k}=1}^{\mathrm{n}} \mathrm{p}\left(\mathrm{E}_{\mathrm{n}} \mid \mathrm{H}_{\mathrm{k}}\right) \times \mathrm{p}\left(\mathrm{H}_{\mathrm{k})} \quad 0.30374 \quad 0.30374\right.
$$

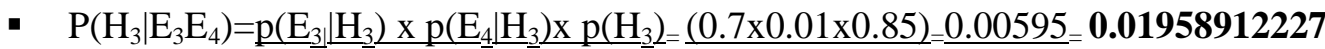

$$
\sum_{\mathrm{k}=1}^{\mathrm{n}} \mathrm{p}\left(\mathrm{E}_{\mathrm{n}} \mid \mathrm{H}_{\mathrm{k}}\right) \times \mathrm{p}\left(\mathrm{H}_{\mathrm{k}}\right) \quad 0.30374 \quad 0.30374
$$

- $\mathrm{P}\left(\mathrm{H}_{4} \mid \mathrm{E}_{3} \mathrm{E}_{4}\right)=\mathrm{p}\left(\mathrm{E}_{3} \mid \mathrm{H}_{4}\right) \times \mathrm{p}\left(\mathrm{E}_{4} \mid \mathrm{H}_{4}\right) \times \mathrm{p}\left(\mathrm{H}_{4}\right)_{2}=\underline{(0.01 \times 0.01 \times 0.7)}=\underline{0.00007}=\mathbf{0 . 0 0 0 2 3 0 4 6 0 2 6}$

$$
\sum_{\mathrm{k}=1}^{\mathrm{n}} \mathrm{p}\left(\mathrm{E}_{\mathrm{n}} \mid \mathrm{H}_{\mathrm{k}}\right) \times \mathrm{p}\left(\mathrm{H}_{\mathrm{k}}\right) \quad 0.30374 \quad 0.30374
$$

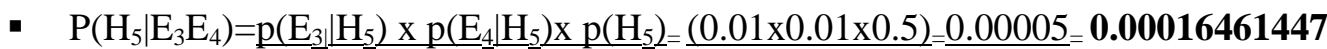

$$
\sum_{\mathrm{k}=1}^{\mathrm{n}} \mathrm{p}\left(\mathrm{E}_{\mathrm{n}} \mid \mathrm{H}_{\mathrm{k}}\right) \times \mathrm{p}\left(\mathrm{H}_{\mathrm{k})} \quad 0.30374 \quad 0.30374\right.
$$

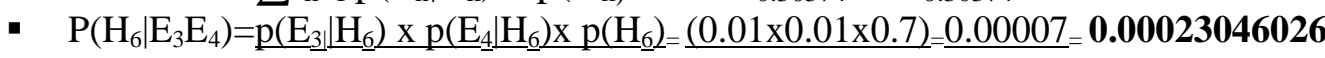

$$
\sum_{k=1}^{n} p\left(E_{n} \mid H_{k}\right) \times p\left(H_{k}\right) \quad 0.30374 \quad 0.30374
$$

- $\mathrm{P}\left(\mathrm{H}_{7} \mid \mathrm{E}_{3} \mathrm{E}_{4}\right)=\mathrm{p}\left(\mathrm{E}_{3} \mid \mathrm{H}_{7}\right) \times \mathrm{p}\left(\mathrm{E}_{4} \mid \mathrm{H}_{7}\right) \times \mathrm{p}\left(\mathrm{H}_{7}\right)=(0.01 \times 0.01 \times 0.5)=0.00005_{2}=\mathbf{0 . 0 0 0 1 6 4 6 1 4 4 7}$

$$
\sum_{\mathrm{k}=1}^{\mathrm{n}} \mathrm{p}\left(\mathrm{E}_{\mathrm{n}} \mid \mathrm{H}_{\mathrm{k}}\right) \times \mathrm{p}\left(\mathrm{H}_{\mathrm{k})} \quad 0.30374 \quad 0.30374\right.
$$

Mencari penyakit dengan nilai bayes tertinggi:
a. Penyakit bercak daun coklat
$=\mathbf{0 . 9 7 9 4 5 6 1 1 3 7 8}$
b. Penyakit bercak daun baur
$=0.00016461447$
c. Penyakit bercak daun putih
$=\mathbf{0 . 0 1 9 5 8 9 1 2 2 2 7}$
d. Penyakit Bakteri Hawar Daun
$=0.00023046026$
e. Penyakit Antrak nose
$=0.00016461447$
f. Penyakit Busuk Pangkal Batang/Akar
$=0.00023046026$
g. Penyakit Selaput Lendir Putih
$=0.00016461447$

Memberikan hasil : 
Berdasarkan hasil diatas didapati bahwa penyakit bercak daun coklat memiliki nilai probabilitas tertinggi dengan nilai probabilitas sebesar 0.97945611378. Maka dapat diambil kesimpulan, bahwa berdasarkan diagnosis yang telah dilakukan penyakit yang diderita tanaman singkong adalah penyakit bercak daun coklat.

\subsection{Perancangan Antarmuka Sistem}

\section{A. Halaman Login}

Pada gambar 5 merupakan tampilan halaman login, dimana saat pengguna tidak memiliki akun, pengguna dapat melakukan registrasi untuk mendapatkan akun. Selain itu, diagnosis dapat dilakukan tanpa menggunakan akun, namun pengguna tidak dapat melihat riwayat hasil diagnosis dan tidak dapat mencetak hasil diagnosis.

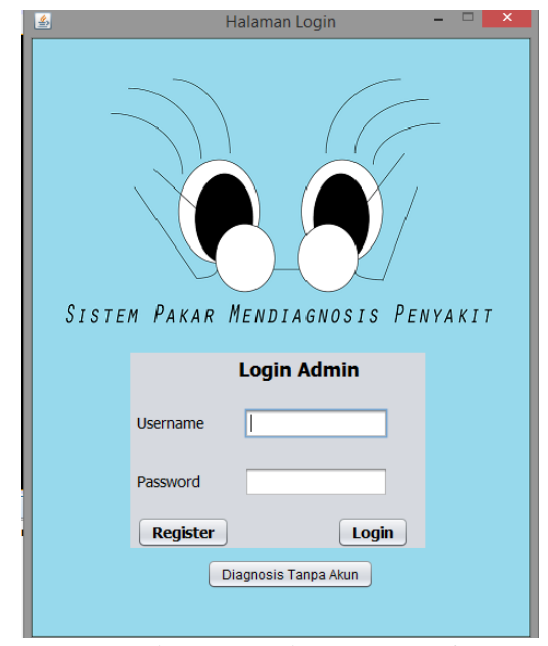

Gambar 5 Halaman Login

B. Halaman Diagnosis

Gambar 6 merupakan tampilan untuk halaman diagnosis dimana pengguna akan diberikan dengan pertanyaan-pertanyaan yang akan membantu sistem mendiagnosis penyakit yang terdapat pada tanaman singkong.

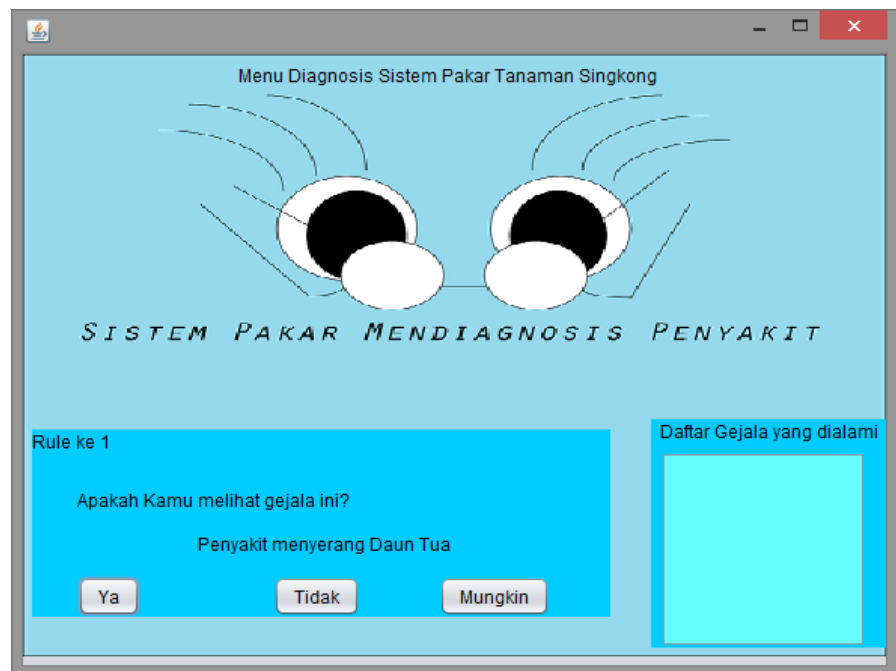

Gambar 6 Halaman Diagnosis 


\section{Halaman Hasil Diagnosis}

Gambar 7 merupakan tampilan untuk hasil diagnosis pengguna yang akan diberikan informasi mengenai penyakit yang menyerang tanaman singkong, beserta saran dengan probabilitas nilai bayes tertinggi dan tampilan diagram yang menyajikan nilai setiap probabilitas gejala.

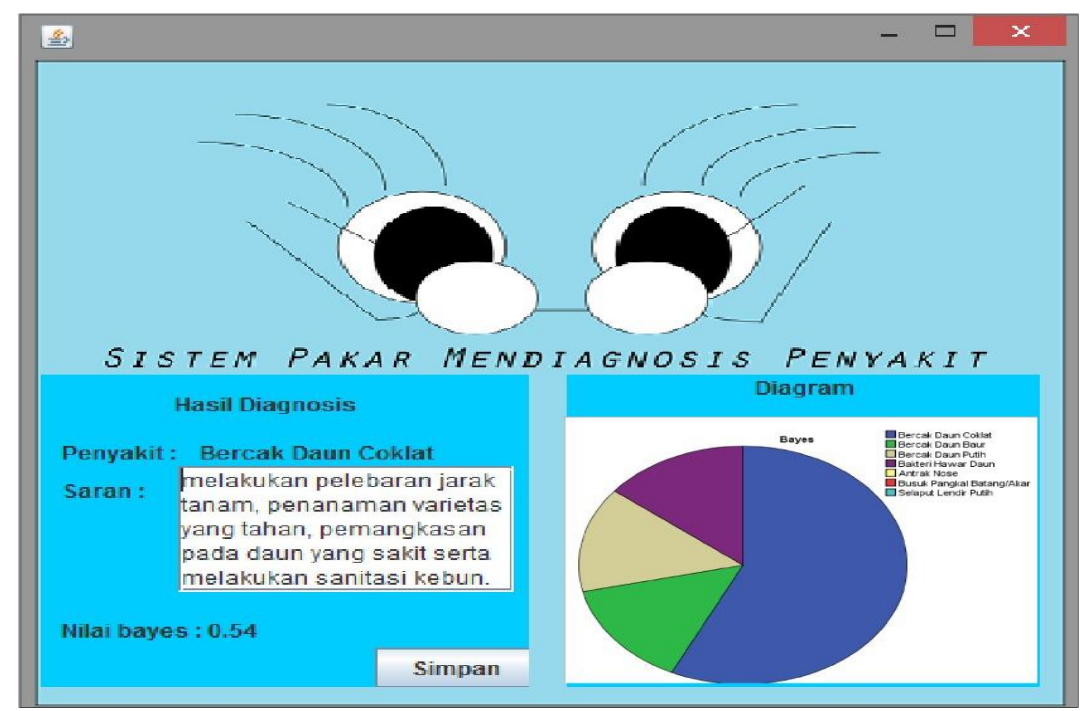

Gambar 7 Halaman Diagnosis

\subsection{Hasil Pengujian}

Skema pengujian sistem dilakukan dengan memasukkan gejala pada tanaman singkong pada sistem dengan hasil diagnosis dari pakar. Berikut pada tabel 2 adalah perbandingan hasil diagnosa.

Tabel 2 Hasil Pengujian

\begin{tabular}{|c|c|c|c|c|}
\hline No & Gejala atau fakta & Hasil dari Sistem & Hasil dari Pakar & Hasil Pengujian \\
\hline 1 & $\begin{array}{l}\text { Daun berkerut, } \\
\text { Daun rontok/gugur, Daun menguning, } \\
\text { Mati pucuk, menyerang permukaan } \\
\text { batang, tangkai daun dan daun, } \\
\text { Terdapat tonjolan pada permukaan } \\
\text { batang,tangkai daun mudah patah, } \\
\text { Daun layu,Pengerutan pada bagian } \\
\text { gabus,Batang mudah patah }\end{array}$ & Antrak nose & Antrak nose & sesuai \\
\hline 2 & $\begin{array}{l}\text { Penyakit Menyerang Daun tua, Daun } \\
\text { Berkerut, Daun rontok/gugur, Daun } \\
\text { Menuning, Daun Layu }\end{array}$ & Bercak Daun Coklat & Bercak daun coklat & sesuai \\
\hline 3 & $\begin{array}{l}\text { Daun layu, Penyakit Menyerang Daun } \\
\text { tua, Daun rontok/gugur, Daun } \\
\text { berlubang }\end{array}$ & Bercak Daun Coklat & $\begin{array}{l}\text { Bercak daun coklat } \\
\text { atau daun putih }\end{array}$ & sesuai \\
\hline 4 & $\begin{array}{l}\text { Mati pucuk, Menyerang Permukaan } \\
\text { batang, tangkai, daun dan daun, } \\
\text { terdapat tonjolan pada permukaan } \\
\text { batang, tangkai daun mudah patah }\end{array}$ & Antrak Nose & Selaput lendir putih & Belum sesuai \\
\hline 5 & $\begin{array}{l}\text { Daun layu, Menyerang pangkal } \\
\text { batang, akar dan umbi, daun gugur } \\
\text { premature, kerusakan warna pada } \\
\text { perakaran }\end{array}$ & $\begin{array}{l}\text { Busuk Pangkal } \\
\text { Batang/Akar }\end{array}$ & $\begin{array}{l}\text { Busuk Pangkal } \\
\text { Batang/Akar }\end{array}$ & sesuai \\
\hline 6 & Daun berkerut, daun rontok/gugur, & Busuk Pangkal & Busuk Pangkal & sesuai \\
\hline
\end{tabular}




\begin{tabular}{|c|c|c|c|c|}
\hline No & Gejala atau fakta & Hasil dari Sistem & Hasil dari Pakar & Hasil Pengujian \\
\hline & $\begin{array}{l}\text { mati pucuk, menyerang permukaan } \\
\text { batang, tangkai daun, dan daun, daun } \\
\text { layu, menyerang pangkal batang akar } \\
\text { dan umbi, daun gugur prematur, } \\
\text { busuk umbi, umbi berwarna gelap dan } \\
\text { berbau busuk }\end{array}$ & batang/Akar & batang/Akar & \\
\hline 7 & $\begin{array}{l}\text { Mati Pucuk, menyerang permukaan } \\
\text { batang, tangkai daun, dan daun, } \\
\text { terdapat tonjolan pada permukaan } \\
\text { batang, tangkai daun mudah patah }\end{array}$ & Antrak nose & Antrak nose & sesuai \\
\hline 8 & $\begin{array}{l}\text { Penyakit Menyerang Daun tua, bercak } \\
\text { coklat, daun berkerut, daun } \\
\text { mengunin, daun kering }\end{array}$ & Bercak Daun baur & Bercak Daun baur & sesuai \\
\hline 9 & $\begin{array}{l}\text { Penyakit menyerang daun tua, bercak } \\
\text { putih coklat pada bagian daun, daun } \\
\text { berkerut }\end{array}$ & Bercak daun coklat & Bercak daun coklat & sesuai \\
\hline 10 & $\begin{array}{l}\text { Penyakit menyerang Daun } \\
\text { Tua,Bercak putih coklat pada bagian } \\
\text { daun,Daun berkerut,Daun } \\
\text { rontok/gugur, } \\
\text { Daun Menguning,Daun } \\
\text { Kering,Bagian tengah bercak } \\
\text { berwarna abu-abu penghasil } \\
\text { jamur,Menyerang daun muda }\end{array}$ & Bercak daun putih & Bercak daun putih & sesuai \\
\hline 11 & $\begin{array}{l}\text { Daun rontok/gugur, Daun Kering, } \\
\text { Menyerang daun dan batang, } \\
\text { Gejala awal berupa lession berwarna } \\
\text { abu-abu lession dibatasi tulang daun } \\
\text { dan membentuk sudut }\end{array}$ & Bercak Hawar Daun & Bercak Hawar Daun & sesuai \\
\hline 12 & $\begin{array}{l}\text { Daun kering, mati pucuk, terdapat } \\
\text { tonjolan pada permukaan batang, } \\
\text { daun layu, menyerang pangkal batang } \\
\text { dan umbi }\end{array}$ & Antrak nose & Antrak nose & sesuai \\
\hline 13 & $\begin{array}{l}\text { Gejala awal berupa lession berwarna } \\
\text { abu-abu, lession dibatasi tulang daun } \\
\text { dan membentuk sudut, lesio meluas } \\
\text { menjadi bercak nekrotik, perlendiran } \\
\text { masa bakteri pada tangkai, heai daun } \\
\text { dan batang }\end{array}$ & Bakteri Hawar Daun & Bakteri Hawar Daun & sesuai \\
\hline 14 & $\begin{array}{l}\text { Terdapat tonjolan pada permukaan } \\
\text { batang, tangkai daun mudah patah, } \\
\text { daun layu }\end{array}$ & Antrak nose & Antrak nose & sesuai \\
\hline 15 & $\begin{array}{l}\text { Bercak putih coklat pada bagian daun, } \\
\text { daun kering, bagian tengah bercak } \\
\text { berwarna abu-abu penghasil jamur, } \\
\text { menyerang daun muda }\end{array}$ & Bercak daun putih & Bercak daun putih & sesuai \\
\hline
\end{tabular}

\section{KESIMPULAN}

Berdasarkan hasil penelitian yang telah dilakukan, maka diperoleh kesimpulan sebagai berikut :

a. Aplikasi sistem pakar ini efektif membantu pengguna yang dalam hal ini para petani, untuk mendeteksi penyakit yang diderita tanaman singkong berdasarkan gejala awal yang terlihat pada daun dan batang tanaman tersebut.

b. Berdasarkan hasil perbandingan antara pakar dan aplikasi sistem pakar yang telah dibuat dari ke 15 uji coba yang telah dilakukan, terdapat 14 diagnosis yang sesuai dengan hasil yang diberikan oleh pakar dan satu diagnosis yang memberikan hasil berbeda dari diagnosis pakar, dengan tingkat keakuratan sebesar $93,33 \%$.

\section{Jurnal Ilmiah SISFOTENIKA}


c. Hasil diagnosis dari aplikasi sistem pakar ini memberikan informasi mengenai detail penyakit yang memiliki nilai persentasi tertinggi, saran penangan penyakit, nilai bayes serta diagram yang berisi persentasi tingkat kemungkinan munculnya keseluruhan penyakit yang ada pada basis pengetahuan. Sehingga petani dapat memiliki gambaran urutan kemungkinan penyakit yang diderita berdasarkan fakta yang dia berikan.

\section{SARAN}

Beberapa pengembangan yang dapat dilakukan untuk penelitian ini antara lain adalah

a. Sistem pakar dapat dikembangkan dengan berbasis website atau aplikasi mobile.

b. Cara penggalian fakta dari pengguna yang tidak terbatas menggunakan kalimat, namun bisa berupa gambar.

c. Sistem dapat dikembangkan dengan menggunakan computer vision, sehingga pengguna hanya perlu mengambil gambar gejala penyakit tanaman dan sistem dapat mendeteksi penyakit yang terjadi pada tanaman.

\section{DAFTAR PUSTAKA}

[1] Pusat Data dan Informasi Pertanian, Kementerian Pertanian (2016). Outlook Ubi Kayu.ISSN:1907-1507.

[2] Badan Pusat Statistik Republik Indonesia (Statistic Indonesia). 2016. Luas panen, produktivitas, produksi tanaman ubikayu seluruh provinsi.

[3] Budiharto, Widodo. 2014. Artificial Intelligent. Andi Offset, Yogyakarta.

[4] Kusrini. (2006). Sistem Pakar, Teori dan Aplikasi. Andi Offset, Yogyakarta

[5] I.O. Awoyelu, R.O Adebisi. 2015. A Preditictive Fuzzy Expert System for Diagnosis of Cassava Plant Diseases. Global Journal Inc (USA). E-ISSN: 2249-4626.

[6] Roselia C. Morco, Fredilyn B. Calanda, Jonathan A. Bonilla. 2017. E-Rice: An Expert System using Rule-Based Algorithm to Detect, Diagnose, and Prescribe Control Options for Rice Plant Diseases in the Philippines. Technological Institute of The Philippines. Quezon City, Philippines.

[7] Fahrul Agus, Hernandha Eka Wulandari, Indah Fitri Astuti. 2017. Expert System With Certainty Factor For Early Diagnosis Of Red Chili Peppers Diseases. Journal of Applied Intelligent System. E-ISSN: 2502-9401.

[8] Delima Sitanggang, Saut D. Siregar, Suryani M.F. Situmeang, Evta Indra. Application of Forward Chaining Mehod to Diagnosis of Onion Plant Diseases. IOP Journal of Physics: Conference Series. 1007012048.

[9] Kristianto, Andi. 2004. Rekayasa Perangkat Lunak (Konsep Dasar). Yogyakarta: Grava Media 